https://doi.org/10.7592/Sator.2017.18.04

\title{
Contemporary Development of the Akyazili Baba Tekke / St. Athanasius in Bulgaria
}

\author{
Yelis Erolova
}

\begin{abstract}
Balkan Ethnology Department of the Institute of Ethnology and Folklore Studies, Bulgarian Academy of Science

kham@abb.bg
\end{abstract}

\begin{abstract}
The paper draws attention to the contemporary development of the late medieval religious architectural complex of Akyazllı Baba tekke in the Bulgarian village of Obrochishte near the Black sea. An overview of historical data, folklore and cultural significance is presented. Over the years, the place is developed as a dual sanctuary of Akyazılı Baba and St. Athanasius of Antioch. It unites different beliefs and legends of the Muslim and Christian local and surrounding population. Nowadays, the tekke is an objective of the local politics aiming to develop cultural tourism. One of the issues discussed in the paper is how the functions of the Akyazılı Baba tekke as a religious center changes and transforms into a cultural attraction. An ethnological study was held in 2009, 2011 and in the beginning of 2014. Data sources from the scientific literature, local government documents and media are used in research methodology.
\end{abstract}

Key words: Sufi architecture, tourist mythology, Akyazılı baba tekke, St. Athanasius of Antioch

\section{Introduction}

There are a number of the Islamic heterodox monuments in Bulgaria that were built during the Ottoman rule (XVI-XIX c). More than fifty tekkes (tekke 'dervish ${ }^{1}$ cloister', 'monastery', 'religious center') with türbe / tülbe (türbe 'tombs', 'mausoleums') are known across the country. They are connected to beliefs that famous religious leaders such as Otman Baba (baba 'father'), Kıdemli Baba, Demir Baba, Hıdır Baba and others from the Late Middle ages were buried there. Their general and specific characteristic is that the Shias and local inhabitants believe that they had abilities to do miracles during their lives and after their deaths. Today they continue to be respected not only by heterodox Muslims, called Kızllbashis / Alevis /Alians ${ }^{2}$, but also by Sunnis and Christians. Their tombs are considered sacred places by the representatives of all religious communities, and they visit them for health, luck and healing. According to Lyubomir Mikov, the architecture of Bektashis ${ }^{3}$ and 
Kizilbashis / Alevis is influenced by Sufism ${ }^{4}$ and it is primarily a manifestation of Shia Islam (2005: 14).

The village of Obrochishte (its old name was Teke, renamed to Obrochishte in 1940) is located between the Bulgarian Northeastern Black sea resorts Albena and Balchik. It is famous for the tekke and türbe of the bektash leader Akyazılı Baba who probably lived in the early XVI century and who was considered "pole of the poles" (kutb $a l-a k t a b$ ) after the death of Otman baba (Mikov 2005: 52). Since the late XIX century, this religious center has been converted into a dual Muslim-Christian sanctuary or bi-ritual sacred place because some local Christians believe that St. Athanasius of Antioch (app. 293/297 - 2 May, 373) was buried there. It has become popular under the name 'monastery' (manastira) among the locals. A number of studies that provide historical, ethnographic and architectural data have been conducted. The purpose of this paper is to analyze how this religious center continues to function as a pilgrimage site for Christians and Muslims and how the local politics try to expand its role as a tourist attraction. Data from the scientific literature, ethnographic fieldwork, and local government documents and media sources is used in research methodology.

\section{Historical Data}

According to academic studies (Gramatikova 2002), it has been proven that Akyazılı (Ibrahim) Baba was a real person, a leader of dervishes and a successor of Otman Baba after his death in 1478-79. He founded a cloister during the first half of the XVI century during the reign of the Ottoman sultan Suleiman I the Magnificent (1522-1560). Many dervishes followed Akyazılı Baba and among them was the Hurufi ${ }^{5}$ poet Yemini, one the revered Bektashi poets in Asia Minor and in the Balkans. He composed an ode "Fazieletname" in 1519 and named Akyazılı Baba as Ibrahim Sani, i.e. a "second Ibrahim" or "second Abraham" (Eyice 1967: 558; Alexiev 2005: 106; Venedikova 2005: 96). Another poet of the 16th century, Muhyeddin Abdal, also mentioned Otman Baba and his succesor Akyazılı Ibrahim in his verses (Mikov 2005: 61; Melikoff 1999: 11-18).

There is a hypothesis that the construction of the Akyazll tekke had started during the reign of sultan Selim I (1512-1520) and 
was completed during the rule of sultan Selim II (1566-1574) (Venedikova 2006: 97; Mikov 2001: 187-196; 2005: 58-60). According to description of Evliya Çelebi, the Ottoman traveler who visited the European province of the Ottoman Empire during the XVII century, the türbe was built by Mihaloğlu Arslan beg who was a follower of Akyazılı Baba (Gadzhanov 1909: 671-672).

Strashimir Dimitrov paid attention to one of the Ottoman register documents (tahrir defter, type of tax register with detailed information about population), which probably dated from the last years of reign of Suleiman the Magnificent (1520-1566). It contains data that confirms the existence of the tekke when Akyazılı died and his türbe was built. It also gives data about the people who were working there: Abdi dede (the elder of the order), Mustafa Aga (türbedar, the guard of the tomb) and three servants. A Gypsy cemaat (community) was described as a part of the inhabitants of tekke and probably they had to work its lands. Nevertheless, the Gypsies were recorded as part of this cloister; they had to pay taxes as they did before. ${ }^{6}$ From the analysis of Strashimirov it can be concluded that in the mid-16th century, the tekke was already established as a religious and socio-economic center (Dimitrov 1994: 90-91).

One of the first descriptions of the Akyazllı Baba tekke can be found in the narrative of Evliya Çelebi (Gadzhanov 1909: 671).

A chandelier with three hundreds candles hung from the ceiling. Each night dervishes light these candles and go to the spiritual contemplation. Under the chandelier there is a small fountain just in the middle of a marbled room. In addition, there are many very high candlesticks donated by various sultans. The furs of slaughtered sacrifices pave the inner area. On each fur dervishes are sitting and working on something. They make wooden spoons, canes for dervishes, horse combs and other things. The Tekke is rich: there is a watermill... sheep, horses, cattle and cornfields. Each night there come about two hundred guests who are well welcomed. Guests can stay up to three days.... Excluding the tekke of Imams Ali and Hussein in Baghdad, there is no another such Tekke anywhere in Turkey and in Persian lands. 
According to Diana Radionova, the religious life of believers is concentrated into the tekke and the cult of Akyazll Baba placed him between ordinary people and the supreme god. "The Dervishleader began to be accepted less as a mentor and teacher and more as an heir of divine essence of the founder of the order." At the same time, the residents of tekkes tried to attract more followers, to increase their income and to justify their requests in front of the local authorities to obtain lands or to get tax rebate (1994: 64).

In the late XIX century Konstantin Irechek and in the early XX century Vasil Kanchov assumed that there was a Christian monastery in the village of Теке/Obrochishte, which was converted by the dervishes into a Muslim temple (Irechek 1974: 897; Kanchov 1901: 11). The assumption did not find any scientific justification, but still remains in the historical memory of the local inhabitants. Most likely it is influenced by the cult to St. Athanasius of the re-settled Bulgarian population from the village Vaysal, Eastern Thrace during the 70s half of the XIX century. At that time the cult of the Akyazllı Baba tekke began to transform into a bi-ritual one, and thus the sanctuary became dual. The Christians "have started to use the prayer house of the village, despite the fact that it is Muslim, and have imposed the cult to that Christian saint, who has been revered in their homes for years" (Radionova 1994: 70-72). The cult of St. Athanasius was adopted later by the Orthodox Rudar Gypsies who settled in the village of Teke/Obrochishte 1919-1940 (Erolova 2010: 109-110).

In fact, the dual cult related to the tekke is not unique, other similar double Muslim-Christian sanctuaries are well-known among the Christian and Muslim population. For example: Ali Baba türbe / St. Elias (Sofia, Knyazhevo), Alatlı Baba türbe / St. John (Shumen region), Hüsein Baba türbe / St. Demetrius (Yambol region), Sarı Saltık Baba / St. Nicholas (Kaliakra) and etc. (Iliev 2006: 39; Yankova 2007: 59-84)

Today, the Akyazılı Baba tekke consists of a park space and two buildings - türbe and imaret (kind of shelter, where dervishes can receive temporary accommodation and perform their rituals). Both constructions have a heptagon form. The sarcophagus is located in the central part of türbe and is northeast-southwest oriented. It is 


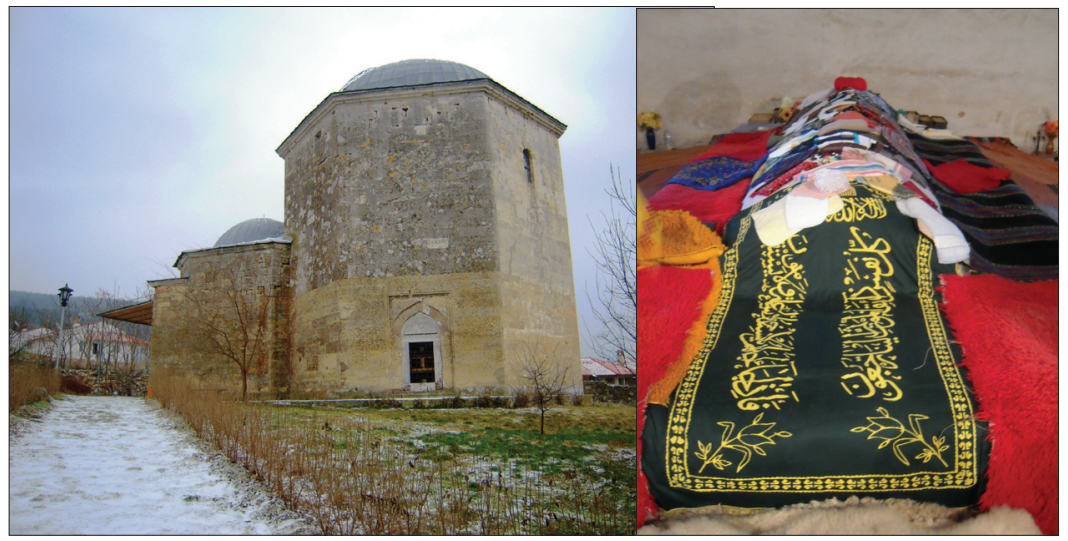

Figures 1-2. The tomb of Akyazll Baba. Photos by Yelis Erolova, 2011.

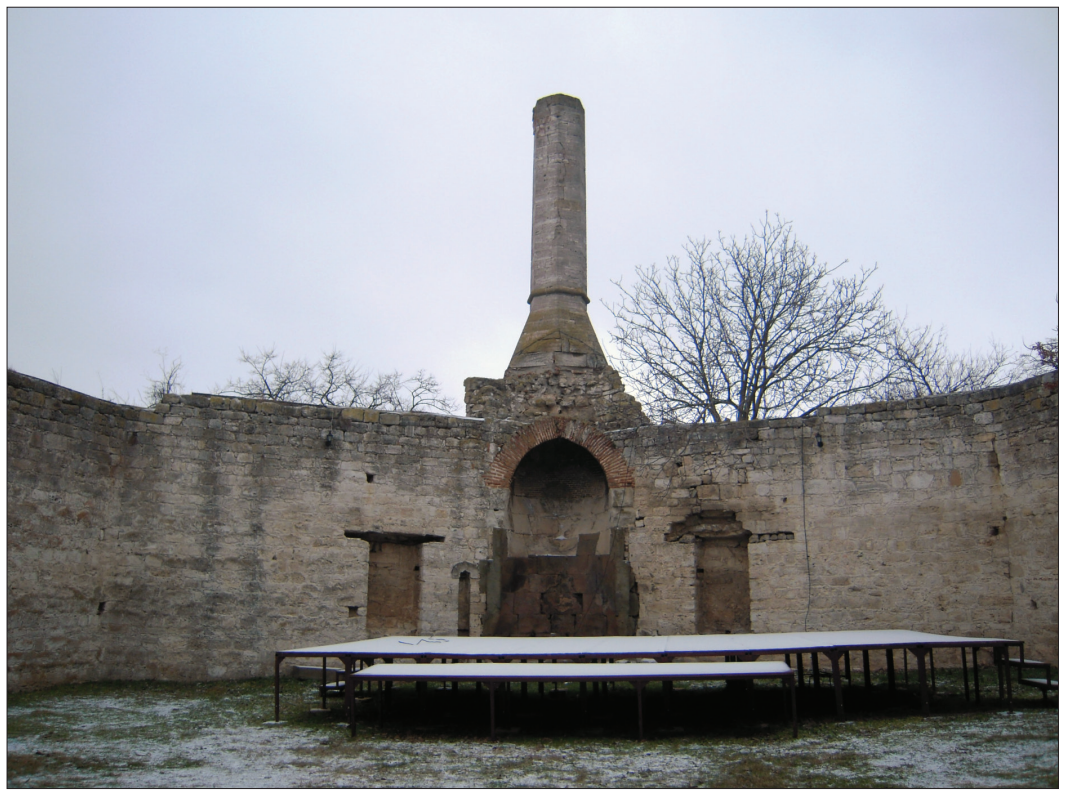

Figure 3. The imaret. Photo by Yelis Erolova, 2011. 
covered in green textile and the place of the head is marked by a turban. The türbe has a prostyle and a roof in form of hemispherical cube. The prostyle's roof has a similar form. The ceiling inside is painted with colorful decoration of stylized geometrical and floral ornaments in baroque style, probably from the late XIX and early XX century.

According to Lyubomir Mikov, reproduction of European type paintings is an example that indicates a process of penetration of European decoration into the Islamic cult architecture in the Balkans (2002: 520-523).

The imaret is located 50 meters north of the tomb. Although it has the same seven-sided form it is significantly larger. Its roof was destroyed in the Russian-Ottoman war 1768-1774. Today only the $5 \mathrm{~m}$ walls and the heptagon stone chimney remain. (Margos 1972)

The heptagon form of the constructions is not chosen randomly. It is related to the number seven, which is the most popular number among the heterodox Muslims in Bulgaria. Lyubomir Mikov and Irene Melikoff interpret this number in connection with the Ismailism conception in Shia Islam, which was developed after VIII century, and its interaction with the Sufi ideology that appeared at the same time. The Ismailis or so-called "Seveners" believe that the Seventh Imam Isma'il ibn Jafar was the last one while the other Shias ("Twelvers") believe in the Twelve Imams and accept Musa al-Kadhim as the true imam. The same seven-sided construction is typical of the tekkes of Otman baba, Kıdemli baba and Demir baba (Melikoff 1999: 14-20; Mikov 2005: 321-329).

\section{The Tekke as a Dual Sanctuary for Muslims and Christians}

The tekke of Akyazll Baba is considered an undisputed monument of the late medieval Muslim architecture by scholars, while the thesis for the tomb of St. Athanasius has not been proven (Margos 1972; Radionova1994: 70). The change of the cult from mono- into bi-ritual during the second half of the XIX century should not be interpreted as "renaming", but as development which unites two saints. At first glance, today, the veneration of Muslim and Christian saints seems to be controversial, but for local inhabitants ${ }^{7}$ 
the so-called "monastery" is mainly a holy place, related to many legends and beliefs about Akyazll Baba and St. Athanasius. The tekke continues to attract the Alevi community from Northeastern Bulgaria as a place of worship and sacrifice (kurban) (Sikimić \& Hristov 2007; Blagoev 2004), although, they prefer to visit a nearby tekke of Demir Baba. Heterodox Muslims come during their holiday Nevruz (March 21st), which marks the beginning of the spring and the New Year. It is connected to the belief that on this day Ali was born and also married Fatima, daughter of the Prophet Mohammed (Georgieva 1991: 74).

Today the village feast (sabor) is celebrated on May 2nd, known as Sveti Atanasiy, just like by the Greeks, for whom the day is associated with the magical power of vegetation (Popov 2002: 113). In 1970 Margarita Vasileva described the custom calendar in the village Obrochiste. She registered that the locals celebrated St. Athanasius on May 2nd. They used to sleep in the tekke on the night of May 1st for health. On the next day they made a kurban (1970, AEIM 683-III, p.84).

In fact, the church has established a double celebration of St. Athanasius - on January, 18th and May 2nd (when he died) - for his exceptional contribution to the preservation of the Orthodox teaching. According to the interlocutors, during the recent years, the local inhabitants have been preparing kurban twice a year in the imaret. Bulgarians gathered on January 18th and Gypsies observed the so-called "summer" St. Athanasius in July (probably the holiday of St. Athanasius the Athonite on July 5th, who is a different saint and lived during the $\mathrm{X}$ century.)

The kurbans made by locals in honor of St. Athanasius aim at bringing health and prosperity, it is related to the mass belief about the saint as a patron of domestic animals and diseases. According to traditional folk narratives, he was a master of diseases with demonic origins such as plague, smallpox and epilepsy. In addition, St. Athanasius is considered an inventor of the blacksmith tongs and founder of the smith's craft together with St. Anthony; this is related to the belief that he has Gypsy or Turkish origins (Popov 2002: 107-110). 
Although carrying out kurban is a tradition that can be interpreted as an element of local identity and culture (Covalcsik 2007: 109136), in Obrochishte, the old practices are not observed anymore. In modern times, the local population does not make common kurbans as they used to do in the recent past. The reasons must be sought in their financial possibilities and in the conversion mostly of the Gypsies to Protestantism, which prohibits sacrifice of animals (Slavkova 2007: 205-247).

Today, we can distinguish the legends and beliefs related to the tekke as a part of the folklore of Alevis, as a part of their religious identity, and of the local inhabitants of Obrochishte as a part of their cultural and local identity. In both cases, the myths contribute to the sanctity of the tekke space and its patrons Akyazılı Baba and St. Athanasius. The mythology related to the folklore profile of both saints can be interpreted according to Mircea Eliade (1961[1952]: 59) as: "The myths are true because they are sacred, because they tell him about sacred beings and events. Consequently, in reciting or listening to a myth, one resumes contact with the sacred and with reality, and in so doing one transcends the profane condition, the "historical situation"".

The inhabitants of Obrochishte and of surrounding settlements believe that both saints have a number of common characteristics, as well as abilities to do miracles - to create big constructions, to heal, to be lords of animals, to "return" and to act as living people, and to do justice. During my field studies, two Muslim and Christian legends with the same story but with different main characters were collected. Akyazılı Baba and St. Athanasius were friends during the Ottoman period. They were exiled in the village because of their religious ideas. St. Athanasius / Akyazılı Baba fell in love with a Turkish / Bulgarian girl, which at that time was not accepted. Then (Ottoman) Turks punished him by death. The day before he was executed, he asked Akyazılı/St. Athanasius to promise to bury him. $\mathrm{He}$ (Akyazılı Baba/St. Athanasius) brought stones and built a tomb in one night. Interlocutors complement their stories by saying that such stones can still be found far from the village; this additionally stresses the magical power of the saints. This contemporary legend has variations registered by most scholars. One of them said that St. Athanasius was killed in the courtyard of the tekke, near a stone 
from which water started to spring. On the other hand, Muslims believe that this stone was the place where Akyazılı Baba bathed (Irechek 1974: 897). According to other story, St. Athanasius was a young shepherd who was in love with a Turkish girl. The ardent believers found out about their love and began to pursue them. St. Athanasius and the Turkish girl decided to commit suicide (Margos 1972).

Like St. Athanasius, who is considered the patron saint of domestic animals, it is also believed that Akyazılı Baba had dominion over animals and they obeyed his will. For example, calves stopped suckling and separated from the cows, dogs ceased barking in Obrochiste, storks stopped flying over the nearby village of Lyahovo. Popular beliefs present St. Athanasius as a shepherd, who herded the cattle for days. Once he asked for a monastery to be built for him. He carried the stones for construction by himself at night, but the villagers stole them during the day to build their own houses. Their cattle began to die. Soon after, St. Athanasius was found murdered in the woods. Then locals decided to fulfill his desire to build a monastery, and inside of it - a tomb. According to the data collected by scholars, Akyazll Baba can appear to the righteous and innocent people when they are asleep or awake. It is believed that if St. Athanasius' slippers and the lower edges of his cloak are wet, he has been walking and grazing the cattle at night. Sometimes the voices of both saints can be heard (Radionova 1994: 65; Alexiev 2005: 114).

Tekke in Obrochishte is associated with its healing power that comes from Akyazılı Baba and St. Athanasius. It is visited by Christians and Muslims (Sunni and Alevis). To be healed, the visitors lie on the sarcophagus and spend the night there. They leave gifts (towels, scarves, socks and other items) on it, light candles and pray; they still continue to do so as an essential expression of reverence of the saint. The belief in the healing abilities of the saints is part of their cult. Evgeniya Ivanova (2001: 75) recorded a similar dual cult of Sarı Baba and St. Nickolas among the locals in the village of Momchilovtsi, Smolyan region, they were and are famous for their healing abilities and they were considered to be from "one faith, because they are healing". The practice of gift-giving can be analyzed in a broader sense by the Marsell Mauss' interpretation of gifts (1990 [1922]). As part of the cult or belief in the magical 


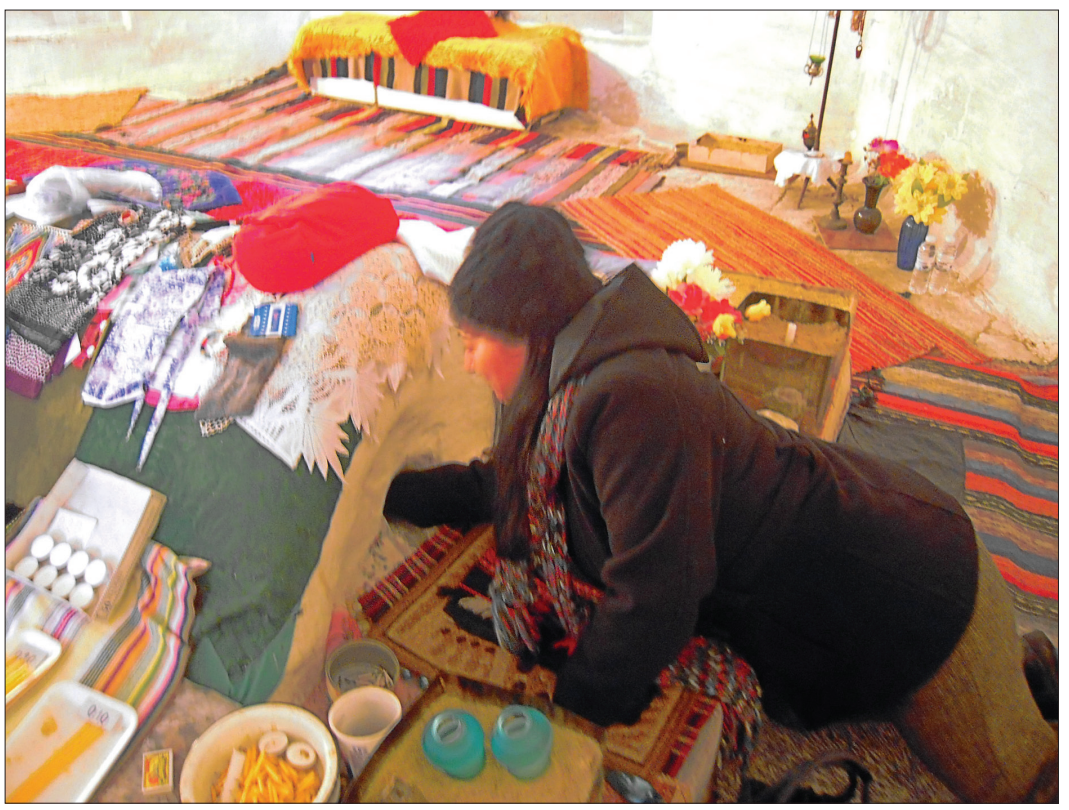

Figure 4. The sarcophagus hole. Photo by Yelis Erolova, 2011.

power of the saints, gifts are not given for "free". They are connected to the hope that the giver will receive health, granting of a wish, or something else in exchange. Thus, the connection between an individual and the saint is established in a spiritual and magic way.

A very common practice in the tekke of Obrochishte, as well as in some other tekkes, is that the visitors tie a cloth or piece of a cloth, a thread on the trees nearby the tomb believing that this action will bring them health. Trees in that area are considered an integral part of the sacred place. They connect the visible world of life and the invisible one of death. To tie personal belongings is a ritual practice that can be interpreted as imitative magic - the illness is transmitted from the living body through the tree to the other world. Margarita Karamihova's study of Otman baba presents a folk belief that the trees around sacred places are inhabited by the souls of the dead and if such tree is cut down, it would result in "punishment" (2002: 57). Together with wood, stone has the same function as a 
mediator between both worlds. 2013 I visited the village of Selcuk in Turkey, famous for the house believed to have been lived in by the Virgin Mary (Meryem Ana) until her death. There was a large stone wall under the house where visitors tie their handkerchiefs and threads and utter their wish.

Nowadays, believers in the tekke of Akyazılı Baba believe that they can check if they have sins or not by checking if they are able to put their hand into the hole at the corner of the sarcophagus. If they succeed - they have no sins, but if they fail, they do.

In the past, chains were hung from the ceiling over the sarcophagus, one of which was longer. If the visitor was able to touch it, he had no sins. A representative of the local Gypsy community explains this action with the magical power of the chains to become longer or shorter depending on the person who tries to touch them. Today, we can see only the hooks in the ceiling where the chains used to be attached. According to interlocutors, there was a time during the socialist period when the remains of the complex were neglected. A shepherd who was herding his flock in the park then took the chains for his working needs.

In addition, local inhabitants believe that the saints have the power "to punish" those who do not believe in their magical abilities. For example, a woman who did not believe in the healing power of St. Athanasius pretended to have a sick hand. She put her hand into the hole of the grave and could not get it out. Several villagers helped her to get her hand out and they succeeded, but in a few days the woman died. (Alexiev 2005: 115) According to another legend, Akyazılı Baba protects the holiness of the land of tekke. Many years ago, some villager decided to establish a farm in this area, but when he went to plow the ground and to destroy the buildings, many of his animals died and he became lame. Terrified, he fled (Radionova 1994: 65).

The faith in the ability of Akyazılı Baba and St. Athanasius "to punish" is a characteristic that is typical of cults of other saints. According to the narrative about Otman baba: "The people of Tarnovo respected the Baba, but they complained about one dervish. Otman baba cursed him to die of leprosy and this happened" (Karamihova 2002: 49). 
The folk beliefs in the saints acting as living people increase their power which leads to a strengthening of faith in them. Although today most of the legends related to the tekke have been forgotten, still the notions of Akyazılı Baba and St. Athanasius are associated with their abilities to do miracles, and the socio-economic function of that place diversifies according to contemporary conditions.

\section{The Tekke as a Cultural Tourist Attraction}

The policy towards the architecture monuments of the Muslim culture in Bulgaria is inconsistent and probably related to the policy towards the Muslim population in the country. Measures for their preservation as cultural objects were applied in certain periods. For example, the infrastructure of the Akyazll Baba tekke was improved during the late 50s of the XX century, which is evidenced by the arch at the main entrance with an inscription that it was built in 1957. Two years earlier archeological excavations had been conducted. It was declared a local cultural monument by the authorities, as most such complexes within the country received such statute in the beginning of 70s (Margos 1972). In modern times, Obrochishte is a part of the administrative territorial structure of Balchik Municipality, Dobrich District and the dervish cloister continues to be defined as a monument of local cultural importance.

The Akyazılı Baba tekke is still related to a number of legends and beliefs by the villagers of Obrochishte and surrounding settlements, but it is not visited by them as it used to be in the recent past. Indeed, it still functions as a place for pilgrimage mainly for the Alevi Muslims. Tourists staying at nearby resorts of Albena and Balchik are the other people who are attracted by the architecture and mythology of that place. According to one of the most important legal documents - Municipal Development Plan (2005-2013) - local heritage is a priority area for the local government, represented by the Municipality Balchik.

Culture and values are stratification of the Hellenistic, Roman, Turkish, Revival and contemporary presence. High cultural and historical value and knowledge of unique monuments of the ancient and medieval Bulgarian era transform the architectural and archaeological reserves of Balchik municipality 
into research fields, a base for tourist products, "cultural backbone" for present generations, and a "bridge" for transferring values to the future. ${ }^{8}$

A new vision of tekke "Akyazll - St. Athanasius" as a cultural object has started to come into being and to be advertised with the purpose of developing tourism and investments. A curator, appointed by the Municipality, works and guides visitors to the complex. Cards, brochures, t-shirts and souvenirs can be bought from the small hall of the tomb.

International festivals of religious songs "St. Athanasius" are held yearly at the middle or the end of May, from 2005 to 2013 at the imaret under the initiative of the Mayor of the village and Municipality of Balchik. National and foreign musical groups from Serbia, Romania, Croatia, Ukraine, Moldova and other countries attended them. Some of the festival issues were included in the cultural development plan of the municipality of Balchik, which provided financial assistance for their realization. Despite the international nature of the event, "St. Athanasius" festival did not attract the villagers, not only because they have other musical preferences, but also because they prefer observing their earlier community holiday on May 2nd. When I visited the festival in 2011, only 5-6 local inhabitants, mainly workers of the village Mayoralty, had an interest in visiting the event.

The local authorities have changed their conception of the "St. Athanasius" festival. According to a Balchik Municipality councilor, a decision to change the musical genres of the festival and more bands to be invited ("festival to be more accessible"), as well as changing the date to May 2nd (corresponding to the community holiday), was made in 2013. On the internet, the tekke and cultural events organized there appear in various tourist and cultural websites, ${ }^{9}$ even on websites selling real estate in the area. ${ }^{\mathbf{1 0}}$

One of the most important measures to popularize the tekke as a cultural and tourist attraction is the municipal project "Improvement of tourist attractions and related infrastructure in the Municipality of Balchik" that was approved for funding in the early 2014 under the Operational Program "Regional Development" (OPRD) 
2007-2013 grant scheme BG161PO001/3.1-03/2010 "Support for the development of natural, cultural and historical attractions", implemented by the Bulgarian Ministry of Regional Development. The project's main objectives are preservation, restoration, exhibition of real cultural values and popularization of the rich cultural-historical heritage of the region with national and local significance. One of the project objectives with "local importance" is "Akyazılı Baba tekke - St. Athanasius". The target groups that will be covered are the Bulgarian and foreign visitors, the citizens of Balchik and the region, officials from the municipal administration and cultural institutions in and out of the Municipality of Balchik. Planned activities include an improvement of tourist infrastructure and construction of the roof for the imaret. Audio-guides in five languages (Bulgarian, English, Russian, Romanian and German) will be provided for the tours of the Bulgarian and foreign visitors. The duration of the project is 24 months. ${ }^{11}$ This project is in the beginning of its implementation, its development and effects cannot be discussed yet.

I must say that during my field studies in 2009, 2011 and 2014, the local population in Obrochiste and the local government representatives in Balchik were very polite and talkative concerning the stories around the tekke. Despite numerous research projects connected to it, interlocutors warned me not to believe everything that is written, feeling competent to answer all the questions that interested me. Moreover, among the locals, most likely local dilettante historians, increasingly spread the perception that Vladislav III Varnenchik (1424-1444), king of Poland (1434-1444) and Hungary (1440-1444), high knyaz of Lithuania (1434-1440) was buried in the tekke. He is considered a significant figure in Bulgarian history as he died in a crusade against the Ottoman troops near Varna in 1444. According to representatives of the local government, archeological excavations must be conducted to prove this hypothesis and if it is true, the complex will become more popular. Regional and national media also reflect this assumption and thus popularize it. ${ }^{12}$

In recent years, such interesting hypotheses that attract the public attention, regardless of whether they are justified or not, have become increasingly popular in various parts of the country, aiming at developing local tourism. For example, such popular 
interpretations are that there are vampires buried in the area of the Black Sea resort of Sozopol, or claims that the wife of Count Dracula originated from the Danube Bulgarian town of Svishtov, or that Spartacus was born in the village of Sklave, near the southern Bulgarian spa resort of Sandanski.

According to Noel Salazar:

Tourism imaginaries are easily re-embedded in new contexts by a process that constantly alters both the imaginaries and the contexts, building on local referents to establish their meaning and value.....Imaginaries often become the symbolic objects of a significant contest over economic supremacy, territorial ownership, and identity. (Salazar 2012: 880)

The legends relating to the tekke of Akyazılı Baba become part of contemporary tourist mythology as an integral part of the development of tourism in recent years in Bulgaria. Tourist attractions try to expand their content out of their regional and national frames and to be directed at a wider variety of consumers (tourists, guests, researchers and so on). In our case, we can notice how local institutions and inhabitants maintain the traditional folklore profiles of the both saints and create a new belief that this is the tomb of the great Vladislav Varnenchik, aiming to give a broader European significance to the history of the complex. The geographical location of the tekke in the tourist area, visited by many Polish, Czech and Russian tourists, further encourages the imagining of new tourists myths, which either do or do not become part of the local identities.

\section{Concluding Remarks}

The dual cult towards Akyazılı Baba and St. Athanasius developed during the 20th century continues to exist. It is largely determined by the needs of the local population in Obrochishte, as well as of the Alevis to believe and to hope, and to have their holy place. Believers find an answer to things human knowledge is powerless to explain through their faith in the miraculous abilities of both saints, who can heal, to help, to observe the sanctity of tekke area and to punish. The cultural marking of the space finds a toponymic expression in buildings, trees, stones and leads to accepting of the tekke as a sacred place protected by both saints. At the same time, the contemporary 
socio-economic conditions create new opportunities for rethinking the significance of this architectural complex and its folklore of the local culture and identity, but also as a tourist attraction. From its establishment until today, the tekke has changed its functions. From a place of spiritual contemplation, which accommodated the travelling dervishes, it has become part of the ritual life of the local and heterodox Muslims in Northeastern Bulgaria, and today it has become part of the cultural tourism vision of the region. Contemporary policy measures related to the complex are undoubtedly a step towards its preservation and popularization. Whether it will be just placed among the regional attractions advertised to tourists and separated from the locals and Alevi community, or whether it will be developed as a attraction with its believers, whether the "holiness" of the saints of Akyazılı Baba and St. Athanasius will be changed or not - these are questions that will remain in the future.

\section{Notes}

${ }^{1}$ Dervish is someone who has religious views influenced by Sufism and follows ascetic way of life. Dervishes are members of Sufi Muslim religious orders/brotherhoods (tariqat in Turkish)

${ }^{2}$ Origin of the so-called heterodox Muslims Kızılbashis / Alevis /Alians in Bulgaria and definition of their religion and culture are disputed (De Jong 1993: 206-209; Georgieva 1991; Norris 1993: 98; Gramatikova 2001: 254-318; Mikov 2005: 17-33). Although they distinguish from the local Muslim Sunnis (majority of who are Turks) by cultural and religious specifics, they look as one community with them in the course of social and political activity. According to the official Population census in Bulgaria in 2001, the total number of the Muslims is 966978 (the Sunnis are 913,957 and the Shias are 53,021. Source: NCCEDI, http://www.nccedi.government. bg/page.php?category=92\&id=247 (Accessed 10.08.2017).

${ }^{3}$ The Bektashis are an Islamic Sufi order, founded by Hadzhi Bektash Veli in the XIII c. The emergence and spread of Bektashism in the Bulgarian lands see in: Norris 1993: 82-137; Melikoff 1999: 11-25; Mikov 2005: 14-17.

${ }^{4}$ Mystical concept in Islam.

${ }^{5}$ Hurufism is a mystical Sufi doctrine, founded by Fażlu l-Lāh Astar-Ābādī, also called Fażlullāh Tabrīzī Astarābādī, or Nāimī in the second half of the XIV c. 
${ }^{6}$ For the tendency of the Gypsies settlement in the Ottoman Empire and their "double" statute among Christians and Muslims, according to the taxes which they had to pay, see in: Marushiakova and Popov 2000: 29-30; $44-46 ; 74-76$.

${ }^{7}$ According to the results of the Official Population census in 2011, 1.921 people live in the village of Obrochishte. They are Orthodox Bulgarians, Orthodox and Protestant Rudar Gypsies, and Muslim Sunni and Protestant so-called Turkish Gypsies by their ethnic and religious belonging (Source: NSI, http://www.nsi.bg/ (Accessed 10.08.2017).

${ }^{8}$ Source: Website of the Municipality of Balchik, http://www.balchik.bg/ (Accessed 10.08.2017).

${ }^{9} \mathrm{http}: / / \mathrm{www}$. namerihotel.com/bg/obrochishte.html

http://poseti.guide-bulgaria.com/NE/dobrich/balchik/obrochishte

http://www.selo359.com/obrochishte (Accessed 12.08.2017).

${ }^{10} \mathrm{http} / / /$ www.mirela.bg/prodavaimoti/\%D1\%81\%D0\%9E\%D0\%B1\%D1\%80 $\% \mathrm{D} 0 \% \mathrm{BE} \% \mathrm{D} 1 \% 87 \% \mathrm{D} 0 \% \mathrm{~B} 8 \% \mathrm{D} 1 \% 89 \% \mathrm{D} 0 \% \mathrm{~B} 5-\mathrm{zxc} 31 \mathrm{q} 1857 . \mathrm{html}$ (Accessed 12.08.2017).

${ }^{11}$ Source: Website of the Municipality of Balchik, http://www.balchik.bg/ (Accessed 12.08.2017).

${ }^{12}$ Source: http://www.dnesplus.bg/News.aspx?n=628502, http://www. temanews.com/index.php?p=tema\&iid=780\&aid=17629 (Accessed 12.08.2017).

\section{Sources}

AIEM - Archives of Ethnographic Institute with Museum, Sofia.

\section{References}

Alexiev, Bozhidar 2005. Folklorni profili na myusyulmanski svetsi v Bulgaria [Folklore Profiles of Muslim Saints in Bulgaria]. Sofia: Akademichno izdatelstvo 'Prof. Marin Drinov'.

Blagoev, Goran 2004. Kurbanyt v traditsiyata na bulgarite mysuylmani [Kurban in the tradition of the Muslim Bulgarians]. Sofia: Akademichno izdatelstvo 'Prof. Marin Drinov'. 
Covalcsik, Katalin 2007. Gurbane as a Representation of Traditional Identity and Culture in an Oltenian Rudar community. Biljana Sikimić and Petko Hristov (eds.). Kurban in the Balkans. Belgrade: Institute for Balkan Studies, Serbian Academy of Sciences and Arts, pp.109-136.

De Jong, Frederick 1993. Problems concerning the origins of the Q1zllbāş in Bulgaria: remnants of the Safaviyya? La shi'a a nell' Impero Ottomano, Vol. 25. Roma: Accademia Nationale dei Lincei, pp. 203-215.

Dnes plus media http://www.dnesplus.bg/News.aspx?n=628502 (Accessed 10.08.2017).

Dimitrov, Strashimir 1995. Kum istoriyata na dobrudzhanskite dvuobredni svetilishta [To the History of the Dobrudzha Biritual Sanctuaries]. Dobrudzha, Vol. 11, pp. 76-97.

Eliade, Mircea 1961 [1952]. Images and symbols. London: Harvill Press.

Erolova, Yelis 2010. Dobrudzha - granitsi i identichnosti [Dobrudzha Borders and Identities]. Sofia: Paradigma.

Eyice, Semavi 1967. Varna ile Balçik arasında Akyazılı Sultan Tekkesi [The Tekke of Akyazılı Sultan between Varna and Balchik]. Belleten, Türk Tarih Kurumu, 31/124. Ekim, Ankara, pp. 551-600.

Gadzhanov, Dimitar (translation) 1909. Patuvane na Evliya Çelebi iz bulgarskite zemi prez sredata na XVII vek [Trip of Evliya Celebi to the Bulgarian land in the middle of XVIIth c.]. Periodchesko spisanie. Bulgarsko Knizhovno Druzhestvo, 70: 639-724.

Georgieva, Ivanichka 1991. Bulgarskite aliani [Bulgarian Alians]. Sofia: Universitetsko izdatelstvo 'Sv. Kliment Ohridski', Istoricheski Muzey Grad Isperih.

Gramatikova, Nevena 2001. Prevratnostite na vremeto i problemut $\mathrm{s}$ identichnostta na alianite $\mathrm{v}$ Bulgaria [Changing Fates and the Issue of Alevi Identity in Bulgaria]. Antonina Zhelyazkova i Jorgen Nielsen (eds.). Ethnologiya na sufitskite ordeni - teoria i praktika. Sofia: IMIR, pp. 254-318 (in Bulgarian), pp. 548-563 (in English).

Gramatikova, Nevena 2002. Otman Baba - One of the Spiritual Patrons of Islamic Heterodoxy in Bulgarian Lands. Études balkaniques, 3. Sofia: Académie bulgare des sciences, pp. 71-102.

Hotels in Obrochishte. http://www.namerihotel.com/bg/obrochishte.html 
Iliev, Boris 2006. Legendite za Demir Baba - Zhelezniyat bashta [Legends of Demir Baba - Iron Father]. Boris Iliev and Anatoliy Kanchev (eds.). Demir Baba - Zhelezniyat bashta. Sofia: IK Gutenberg, pp. 12-46.

Irechek, Konstantin 1974. Patuvaniya po Bulgaria[Trips in Bulgaria]. Sofia: Nauka i izkustvo.

Ivanova, Evgeniya 2001. Tyurbeto na Sara Baba nad s. Momchilovtsi, Smolyansko [The Sara Baba Tomb over the Village of Momchilovtsi, Smolyan Region]. Bulgarska Ethnologia, XXVII (3), pp. 66-77.

Kanchov, Vasil 1901. Iz Bulgarska Dobrudzha. Patni belezhki [In Bulgarian Dobrudzha. Trip notes]. Sofia.

Karamihova, Margarita 2002. Prikazki za Osman Baba [A Tale for Osman Baba]. Sofia: Akademichno izdatelstvo 'Prof. Marin Drinov'

Margos, Ara 1972. Teketo Ak Yazılı baba: patevoditel [The Ak Yazılı Baba tekke: Guidebook]. Tolbuhin: Okrazhen istoricheski muzei Tolbuhin.

Marushiakova, Elena \& Popov, Vesselin 2000. Gypsies in the Ottoman Empire. Sofia: Litavra.

Mauss, Marcel 1990 [1922]. The Gift: forms and functions of exchange in archaic societies. London: Routledge.

Melikoff, Irene 1999. Razmisli po problema bektashi-alevi [Reflections on the Bektashi-Alevi Problem]. Galina Lozanova and Lyubomir Mikov (eds.). Islyam and kultura. Sofia: IMIR, pp. 11-24.

Mikov, Lyubomir 2001. Spetsifika na sufitskata arhitektura v Bulgaria (XVI-XX vek) [Specifics of the 16th - 20th c. Sufi Architecture in Bulgaria]. Antonina Zhelyazkova i Jorgen Nielsen (eds.). Ethnologiya na sufitskite ordeni - teoria i praktika. Sofia: IMIR, pp. 187-219 (in Bulgarian), pp. 502-531 (in English).

Mikov, Lyubomir. 2002. Interiorna ukrasa na bektashkite grobnitsi v Bulgaria (stenopisi, kartini, shtampi) [Interior Decoration of Bektashi Tombs in Bulgaria (Mural Painting, Pictures, Prints)]. Rositsa Gradeva and Svetlana Ivanova (eds.). Myusulmasnkata kultura po bulgarskite zemi, 2. Sofia: IMIR, pp. 520-550 (in Bulgarian).

Mikov, Lyubomir 2005. Izkustvoto na heterodoksnite myusyulmani v Bulgaria (XVI-XX vek). Bektashi i kuzulbashi/alevii [The Art of Heterodox Muslims in Bulgaria (XVI-XX century). Bektaşi and Kızılbaş / Aleviî]. Sofia: Akademichno izdatelstvo 'Prof. Marin Drinov'. 
Mirella Real Estate Agency. http://www.mirela.bg/prodavaimoti/\%D1\%81 \%D0\%9E\%D0\%B1\%D1\%80\%D0\%BE\%D1\%87\%D0\%B8\%D1\%89\%D0\%B5zxc31q1857.html (Accessed 14.02.2014).

Norris, Harry 1993. Islam in the Balkans: Religion and Society between Europe and the Arab world. Columbia: University of South Carolina Press.

Obschina Balchik [Municipality of Balchik]. http://www.balchik.bg (Accessed 10.08.2017).

Popov, Rachko 2002. Svetsi i demoni na Balkanite [Saints and Demons in the Balkans]. Sofia: Svyat i nauka.

Population census 2001. NCCEDI [National Council for Cooperation on Ethnic and Integration Issues]

http://www.nccedi.government.bg/page.php?category=92\&id=247 (Accessed 10.08.2017).

Radionova, Diana 1994. Teketo na Ak yazili baba pri selo Obrochishte, Balchishko [The Akyazılı Baba in Obrochishte, the region of Balchik]. Dobrudzha, 11 (1), pp. 61-75.

Respublika Balgaria. Nacionalen Statisticheski Institut [National Statistic Institute]. http://www.nsi.bg/ (Accessed 10.08. 2017).

Salazar, Noel 2012. Tourism Imaginaries: A Conceptual Approach. Annals of Tourism Research, UK. Vol. 39 (2). Imprint: ELSEVIER, pp. 863-882.

Selo 359.com. http://www.selo359.com/index.php (Accessed 10.08.2017).

Sikimić, Biljana \& Hristov, Petko (eds.) 2007. Kurban in the Balkans. Belgrade: Institute for Balkan Studies, Serbian Academy of Sciences and Arts.

Slavkova, Magdalena 2007. Evangelical Gypsies in Bulgaria: way of life and performance of identity. Romani Studies, Vol. 17 (2), pp. 205-247.

Turism in Obrochishte. Guide Bulgaria. Com. http://poseti.guide-bulgaria. $\mathrm{com} / \mathrm{NE} / \mathrm{dobrich} / \mathrm{balchik} / \mathrm{obrochishte}$ (Accessed 10.08.2017).

Vagalinska, Irina 2011-2017. Za kostite na edin kral. Tema. http://www.temanews.com/index.php?p=tema\&iid=780\&aid=17629 (Accessed 10.08.2017).

Vasileva, Margarita 1970. Kalendarni obichai [Kalendar Customs]. Archiv of Ethnographic Institute with Museum (AEIM), 683-III. 
Venedikova, Katerina. 2006. Iz zhitiyeto na Demir Baba [A Fragment from Saint's life of Demir Baba]. Boris Iliev and Anatoliy Kanchev (eds.). Demir Baba - Zhelezniyat bashta. Sofia: IK Gutenberg, pp. 96-103.

Yankova, Veneta 2007. Toposi, pamet, identichnosti (Kym folklore na myusyulmanite $i$ hristiyanite $v$ Shumensko) [Topoi, Memory, Identities. (The Folklore of the Muslims and Christinas in Shumen region)]. Veliko Tarnovo: Faber. 


\section{ELM Scholarly Press \\ SATOR 18}

http://dx.doi.org/10.7592/Sator.2017.18

\section{BALKAN AND BALTiCUM}

Current Studies in the Postsocialist Space

Edited by

Ekaterina Anastasova and Mare Kõiva

Tartu 2017 
Editors and compilers: Ekaterina Anastasova, Mare Kõiva Series "Sator" editor: Mare Kõiva

Language editors: Liisa Vesik, Lii Liin

Cover photo: Jaak Kikas, 2017 "Autumn in Tartu"

International committee

Tiiu Jaago (Tartu University); Reet Hiiemäe (Estonian Literary Museum); Mare Kalda (Estonian Literary Museum); Tarmo Kulmar (Tartu University); Nikolay Kuznetsov (Estonian Literary Museum); Aado Lintrop (Estonian Literary Museum); Emily Lyle (School of Scottish Studies in Edinburgh); Mirjam Mencej (Ljubljana University); Jonathan Roper (Tartu University); Marju Kõivupuu (Tallinn University); Ülo Valk (Tartu University); Tatjana Vladõkina (Institute of Udmurtian History, Language and Literarture, Izhkar); Irina Vinokurova (Institute of Karelian History, Language and Literarture in Petroskoi); Ergo-Hart Västrik (Tartu University)

Supported by Estonian Academy of Sciences, Bulgarian Academy of Sciences, the Centre of Excellence in Estonian Studies (CEES, European Regional Development Fund) and is related to research projects IRG 22-5 (Estonian Research Council).

\section{$\boldsymbol{C} E \mathbf{E} \times \begin{aligned} & \text { Centre of excellence } \\ & \text { in Estonian Studies }\end{aligned}$}

Series "Sator. Artikleid usundi- ja kombeloost", 18 http://www.folklore.ee/rl/pubte/ee/sator/sator18/

ISSN 1736-0323 (online)

ISBN 978-9949-586-58-5 (printed)

ISBN 978-9949-586-61-5 (online) ISSN 1406-2011 (printed)

DOI: 10.7592/Sator.2017.18

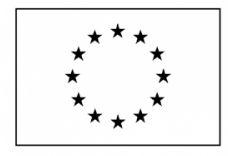

European Union European Regional Development Fund

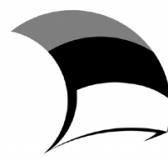

Investing in your future

\section{EUROPEAN UNION}

Regional Development Fund

Investing in your future
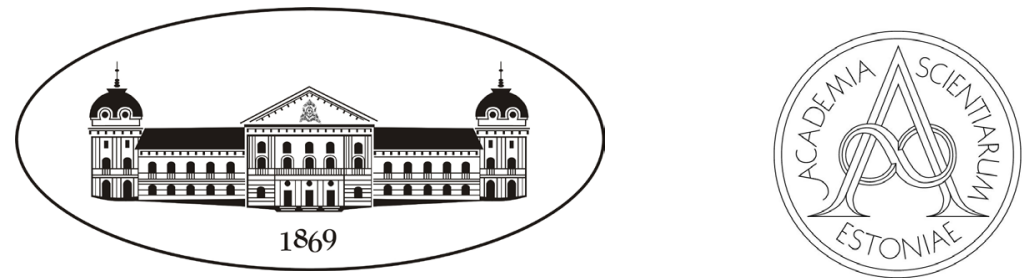


\section{Contents}

Preface

Mare Kõiva, Ekaterina Anastasova

CONSTRUCTING IDENTITY AND SOCIAL TIES

Ethnographic Studies on the Montenegrin

Festive Costume as a National Symbol

Sofiya Zahova

Social Ties of Bulgarians and Rudari in the Mediterranean Countries

Magdalena Slavkova

\section{RECASTING RELIGION AND \\ RELIGIOUS IDENTITY}

Contemporary Development of the Akyazili

Baba Tekke / St. Athanasius in Bulgaria

Yelis Erolova

Turkish Religious Identity in Bulgaria

94

in the Last Twenty-Four Years (1989-2013)

Mila Maeva

The Feast of Cyril and Methodius in Bessarabia and Crimea, Ukraine

Ekaterina Anastasova 
The Saints of Death in the Traditions

of the Balkan People

Rachko Popov

\section{CONSTRUCTING NEW SPIRITUALITY}

New Trends in the Study of Religion in Estonia -

Contemplations in the Grey Zone between

Religion and Science

Tõnno Jonuks

Constructing New Spirituality in Modernity -

the Case of the White Brotherhood in Bulgaria

Svetoslava Toncheva

Constructing Contemporary Periodical and

Occasional Rituals

Mare Kõiva

The Making of a Sacred Place:

221

An Example of Constructing Place Identity in the Contemporary Mentality

Reet Hiiemäe

\section{CHANGING TRADITIONS}

Bridge Over the Rainbow. Animal Burials and

Animal Cemeteries in Post-Socialist Estonia

Marju Kõivupuu

Simple Hide-and-seek at its Core: Play Features and the Game of Geocaching

Mare Kalda 